\title{
WEDANUS FORMOSANUS N. SP. (POECILOSTOMATOIDA, RHYNCHOMOLGIDAE), A COPEPOD PARASITIC IN A SCLERACTINIAN CORAL OF TAIWAN
}

\author{
BY \\ YU-RONG $\mathrm{CHENG}^{1}$ ), JU-SHEY $\mathrm{HO}^{2,3}$ ) and CHANG-FENG DAI ${ }^{1}$ ) \\ 1) Institute of Oceanography, National Taiwan University, No. 1, Section 4, Roosevelt Road, \\ Taipei 106, Taiwan \\ 2 ) Department of Biological Sciences, California State University, 1250 Bellflower Boulevard, \\ Long Beach, California 90840-3702, U.S.A.
}

\begin{abstract}
A new species of poecilostomatoid copepod belonging to the Rhynchomolgidae, Wedanus formosanus, is described. It was found living in the polyps of a scleractinian coral, Goniopora minor Crossland, 1952, collected off Wanlitong in the southern part of Taiwan. The new species can be distinguished from its sole congener, Wedanus inconstans Humes, 1978, by the armature on the exopod of legs 1, 2, 3, and 4, and on the endopod of legs 3 and 4.
\end{abstract}

\section{RÉSUMÉ}

Une nouvelle espèce de copépode poecilostomatoïde appartenant à la famille des Rhynchomolgidae, Wedanus formosanus, est décrite. Elle a été trouvée dans les polypes des coraux Scléractiniaires, Goniopora minor Crossland, 1952, récoltés au large de Wanlitong dans la partie méridionale de Taiwan. La nouvelle espèce se distingue de son unique congénère, Wedanus inconstans Humes, 1978, par l'armature de l'exopodite des pattes natatoires 1, 2, 3, et 4, et celle de l'endopodite des pattes 3 and 4 .

\section{INTRODUCTION}

Animal associates are commonly found with cnidarians (Patton, 1972, 1976, 1994; Johnsson et al., 2006; Oigman-Pszczol \& Creed, 2006). In the past 40 years, many copepods have been found living in various degrees of association with hard and soft corals. The corals offer not only food but also shelter, thus allowing a

3) e-mail: jsho@csulb.edu 
greater diversity of symbiotic modes of life than do many other types of sedentary host (Patton, 1976).

At the time of the establishment of Rhynchomolgidae Humes \& Stock, 1972, the family was a monotypic taxon containing only Rhynchomolgus corallophilus Humes \& Ho, 1967. However, it is now the largest family of poecilostomatoid copepods with members occurring in association with various marine invertebrates, such as cnidarians (Hydrozoa and Anthozoa), mollusks (Bivalvia, Gastropoda, and Cephalopoda), and echinoderms (Asteroidea and Ophiuiroidea) (Ho \& Kim, 2001). According to Boxshall \& Halsey (2004) the family is now comprising over 230 species in 43 genera, with a great majority of them living on or in cnidarians, in particular, in alcyonarians.

Twenty-three species of rhynchomolgids are so far known to associate exclusively with scleractinian corals. It is interesting to point out that 12 of those 23 rhynchomolgids are classified in monotypic genera. One of them is Wedanus inconstans Humes, 1978. Thus, we are pleased to report the discovery of the second species of this genus. The associate copepods were found in the washings of a colony of Goniopora minor Crossland, 1952 taken from Taiwan. The first species of this genus was reported from Goniopora tenuidens (Quelch, 1886) collected off Halmahera in the Moluccas by Humes (1978).

\section{MATERIAL AND METHODS}

Fragments of scleractinian coral, Goniopora minor, were collected by SCUBA diving at depths from 5 to $10 \mathrm{~m}$, placed in a plastic bag while in the water, and transported to the laboratory for examination of copepod associates. To collect the copepod symbionts, the coral together with the sea water in the bag was emptied into a bucket to which sufficient $95 \%$ ethyl alcohol was added to make an approximately $5 \%$ solution. Then the water was poured through a fine net (mesh size approximately $100 \mu \mathrm{m}$ ). The copepods were picked from the sediment retained in the net and preserved in $70 \%$ ethanol. They were later cleared in $85 \%$ lactic acid for 1 to $2 \mathrm{~h}$, then dissected on a wooden slide under a dissecting microscope (Humes \& Gooding, 1964). The removed body parts and appendages were examined under a compound microscope with a series of magnifications up to $1000 \times$. All drawings were made with the aid of a drawing tube. 


\section{Wedanus formosanus $\mathrm{n}$. sp. (figs. 1-2)}

Material examined. - Four o o from Goniopora minor Crossland, 1952 collected at $5 \mathrm{~m}$ depth, at Wanlitong, southern Taiwan on 28 January 2007. Holotype (NTUIO-COPEPOD 0007) deposited in the Institute of Oceanography, National Taiwan University, Taipei, Taiwan. Remaining specimens dissected and kept in the senior author's private collection.

Female. - Body (fig. 1A, B) elongate, with sensilla on body surface (fig. 1C), 2.04 (1.98-2.10) $\mathrm{mm}$ long (excluding setae on caudal rami) and 0.32 (0.280.36) $\mathrm{mm}$ wide, based on 4 specimens. Segmentation of body indistinct, except for genital double-somite and abdomen (fig. 1C). Genital double-somite as wide as fifth pediger, with areas of attachment of egg sacs located dorso-laterally. Egg sacs not seen. Abdomen (fig. 1C) 3-segmented, first somite largest. Caudal ramus (fig. 1D) small, longer than wide, $46 \times 23 \mu \mathrm{m}$, located subterminally on ventrolateral side of anal somite; bearing spinules on ventral and lateral sides in addition to 1 long and 4 short setae in terminal and subterminal regions.

Rostral area round and protruded in dorsal view, without snout-like ventral lobe. Antennule (fig. 1E) slender, 7-segmented; armature: 4, 13, 5, 4, 4+1 aesthetasc, $2+1$ aesthetasc, and $7+1$ aesthetasc. Antenna (fig. 1F) 4-segmented; armature 1,1,2, and 1 claw plus 3 setae; all segments bearing spinules, except for proximal segment (coxobasis). Mandible (fig. 1G) stout; convex edge with closely packed teeth; concave edge beyond deep indentation with row of slender teeth followed by row of closely packed teeth. Maxillule (fig. 1H) small, tipped with 2 terminal and 1 subterminal setae. Maxilla (fig. 1I) 2-segmented; proximal segment large, ornamented with a patch of spinules on anterior surface; distal segment small, bearing a small, outer seta and a spiniform, inner seta in basal region of terminal lash, which is relatively short, with spines along medial edge. Maxilliped (fig. 1J) 3-segmented; proximal segment largest, but unarmed; middle segment with 1 small, simple seta and a large, bilaterally pinnate spine; distal segment smallest, tipped with 2 large, barbed spines and 2 naked setae (fig. 1J, see inserted drawing).

Legs 1-4 (fig. 2A, B, C, D) with 3-segmented rami, except for the endopod of leg 4, which is 2-segmented. Formula of spines (in Roman numerals) and setae (in Arabic numerals) as follows:

$\begin{array}{lllll} & \text { Coxa } & \text { Basis } & \text { Exopod } & \text { Endopod } \\ \text { Leg 1 } & 0-0 & 1-0 & \text { I-0; I-0; III,3 } & 0-1 ; 0-1 ; \text { I,4 } \\ \text { Leg 2 } & 0-0 & 1-0 & \text { I-0; I-1; II,3 } & 0-1 ; 0-1 ; \text { III,2 } \\ \text { Leg 3 } & 0-0 & 1-0 & \text { I-0; I-1; II,2 } & 0-1 ; 0-2 ; 1 \\ \text { Leg 4 } & 0-0 & 1-0 & \text { I-0; 0-1; II,2 } & 0-1 ; 2\end{array}$

Outer margin of endopod in legs 1 (fig. 2A) and 2 (fig. 2B) fringed with a row of setules, but naked in legs 3 (fig. 2C) and 4 (fig. 2D). Outer distal corner of terminal segment of legs 3 (fig. 2C) and 4 (fig. 2D) protruded into a sharp spine. Leg 5 
A

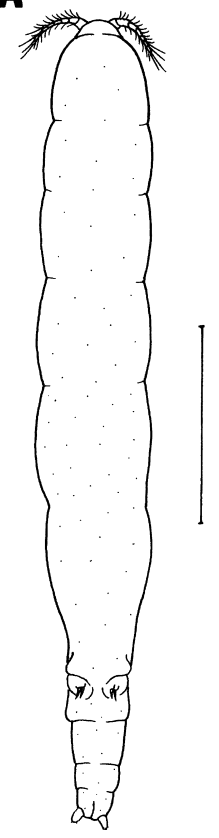

B

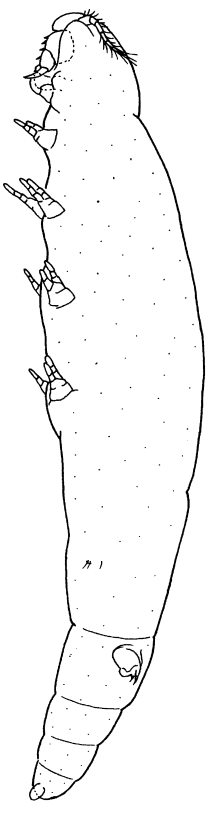

C

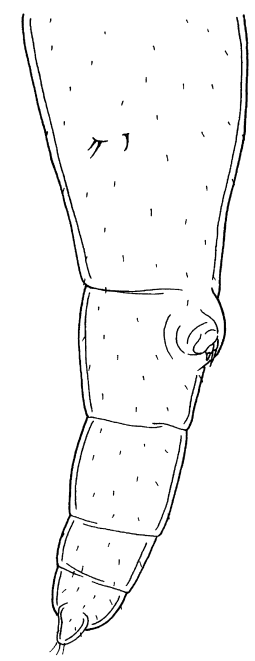

$\mathbf{F}$

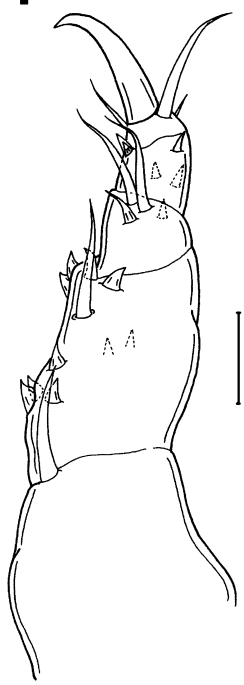

G
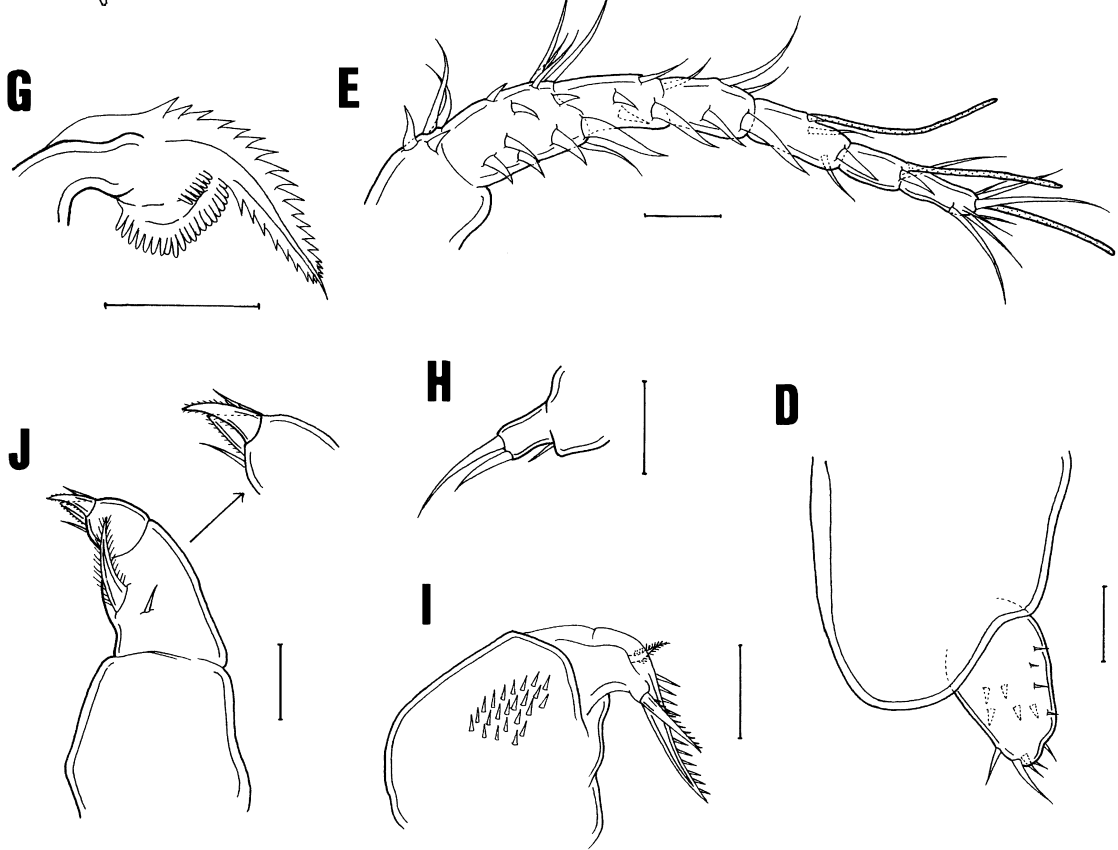

D

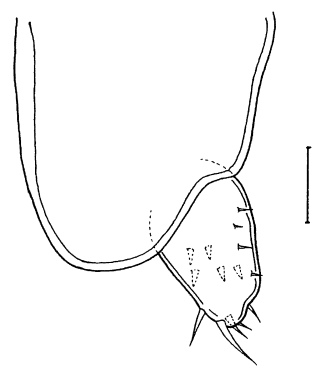

Fig. 1. Wedanus formosanus n. sp., female. A, habitus, dorsal; B, habitus, lateral; C, urosome, lateral; $\mathrm{D}$, right half of anal somite and caudal ramus, dorsal; E, antennule, dorsal; F, antenna, anterior; G, mandible, ventral; H, maxillule, anterior; I, maxilla, anterior; J, maxilliped, posterior. Scale bar: 0.5 $\mathrm{mm}$ in $\mathrm{A}, \mathrm{B}$ and $\mathrm{C} ; 0.02 \mathrm{~mm}$ in D-J. 

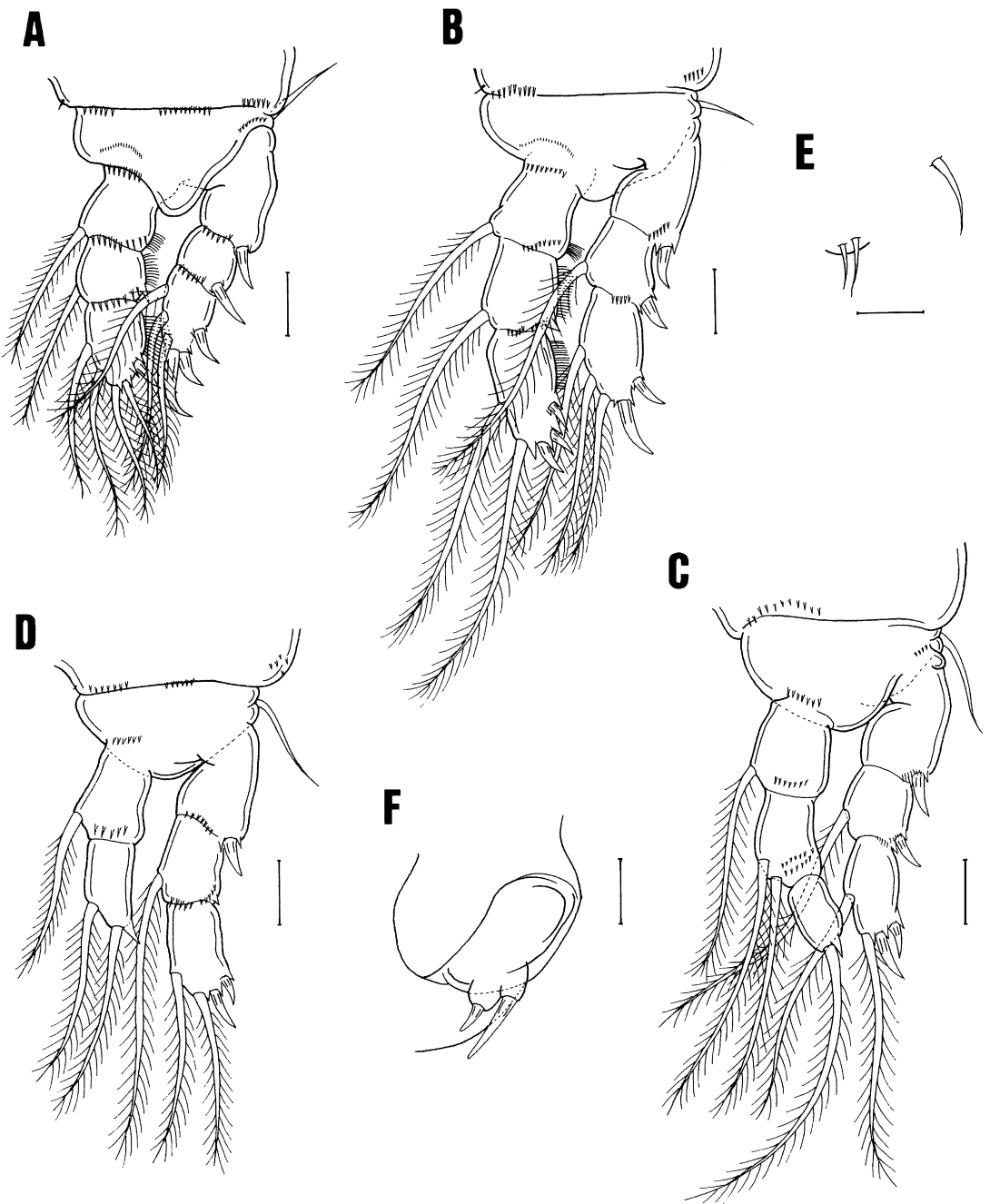

Fig. 2. Wedanus formosanus n. sp., female. A, leg 1, anterior; B, leg 2, anterior; C, leg 3, anterior; D, leg 4, anterior; E, leg 5, anterior; F, leg 6, dorsal. Scale bar: $0.02 \mathrm{~mm}$ in A-F.

reduced to 3 setae occurring in two groups on lateral side of fifth pediger (fig. 1C), one dorsally and two ventrally (fig. 2E). Leg 6 as in most poecilostome copepods represented by two spiniform, blunt setae on egg sac attachment area (fig. 2F).

Male. - Unknown.

Etymology. - The species name formosanus is taken from the Portuguese word "Formosa" which was the name of Taiwan in the $16^{\text {th }}$ century.

Remarks. - As in the case of Wedanus inconstans, we have also found abnormality in the armature of the legs. One dissected female has one (instead of two) medial seta on the right, middle, endopodal segment of its leg 3, and another 


\section{TABLE I}

Differences in the armature of the two species of Wedanus

\begin{tabular}{lll}
\hline Leg ramus & W. inconstans Humes & W. formosanus n. sp. \\
\hline Leg 1 exopod & I-0; I-1; IV,4 & I-0; I-0; III,3 \\
Leg 2 exopod & I-0, I-0; III,4 & I-0; I-1; II,3 \\
Leg 3 exopod & I-0; I-1; II,3 & I-0; I-1; II,2 \\
endopod & $0-0 ; 0-2 ;$ I, 1 & $0-1 ; 0-2 ; 1$ \\
Leg 4 exopod & I-0; I-1; II,3 & I- $0 ;$ I- $1 ;$ II, 2 \\
endopod & $0-0 ;$ I,2 & $0-1 ; 2$ \\
\hline
\end{tabular}

dissected female has three (instead of two) spines on the right, terminal, exopodal segment of its leg 4.

The new species can easily be distinguished from $W$. inconstans by the armature on the four pairs of legs. Those differences are summarized in table I. With these magnitude of differences, one might cherish the idea of establishing formosanus in a genus separated from Wedanus. However, at the moment when our knowledge of the copepod associates of scleractinians is still in its infancy and many species of rhynchomolgids are classified into monotypic genera, we shall refrain from splitting them up and keep them together for now to advocate their closeness. Separation of them can be done when more understanding of the rhynchomolgids will have been reached.

\section{ACKNOWLEDGEMENTS}

We thank Shang-Yin Liu, Ming-Jay Ho, Anyi Cheng, Sharon Horng, Tsai-Ming Lu, Cheing-hwa Huang, and Yu-Chu Lin for their assistance in the field. This study was partially supported by a grant from the National Science Council (NSC952611-M002-011-MY3) and the Fisheries Agent of the Council of Agriculture in Taiwan. Completion of the manuscript of this paper was aided by a grant from the Paramitas Foundation to J.S.H.

\section{REFERENCES}

Boxshall, G. A. \& S. H. Halsey, 2004. An introduction to copepod diversity. Ray Society, London, 166: 1-966.

Ho, J. S. \& I. H. KIM, 2001. New species of Doridicola (Copepoda, Rhynchomolgidae) from Thailand, with a cladistic analysis of the genus. Journ. Crust. Biol., 21(1): 78-89.

Humes, A. G., 1978. A poecilostome copepod parasitic in a scleractinian coral in the Moluccas. Hydrobiologia, 58(2): 119-128.

HumES, A. G. \& R. U. GOODING, 1964. A method for studying the external anatomy of copepods. Crustaceana, 6: 238-240. 
Johnsson, R., E. Neves, G. M. O. Franco \& F. L. Da Silveria, 2006. The association of two gall crabs (Brachyura: Cryptochiridae) with the reef-building coral Siderastrea stellata Verrill, 1868. Hydrobiologia, 559(3): 379-384.

Oigman-Pszczol, S. S. \& J. C. Creed, 2006. Distribution and abundance of fauna on living tissues of two Brazilian hermatypic corals (Mussismilia hispida (Verrill, 1902) and Siderastrea stellata Verrill, 1868). Hydrobiologia, 563(2): 143-154.

PATtON, W. K., 1972. Studies on the animal symbionts of the gorgonian coral, Leptogorgia virgulata (Lamarck). Bull. mar. Sci., 22: 419-431.

-, 1976. Animal associates of living reef corals. In: O. A. JONES \& R. ENDEAN, Biology and geology of coral reefs, 3, Biology (2): 1-33. (Academic Press, New York).

- -, 1994. Distribution and ecology of animals associated with branching corals (Acropora spp.) from the Great Barrier Reef. Bull. mar. Sci., 55: 193-211. 